Article

\title{
One-Step Assembly of Fluorescence-Based Cyanide Sensors from Inexpensive, Off-The-Shelf Materials
}

\author{
Gregory E. Fernandes* $*$, Ya-Wen Chang $₫$, Akash Sharma and Sarah Tutt \\ Department of Chemical Engineering, Texas Tech University, Lubbock, TX 79409-3121, USA; \\ ya-wen.chang@ttu.edu (Y.-W.C.); akash.sharma@ttu.edu (A.S.); sarah.tutt@ttu.edu (S.T.) \\ * Correspondence: gregory.fernandes@ttu.edu
}

Received: 10 July 2020; Accepted: 7 August 2020; Published: 11 August 2020

check for updates

\begin{abstract}
We report a simple and versatile approach to assemble sensitive and selective fluorescence "turn-on" sensors for cyanide by combining three off-the-shelf materials; namely fluorescent dye, 1-vinyl imidazole polymer, and cupric chloride. The cyanide-sensing species is a non-fluorescent fluorophore-polymer- $\mathrm{Cu}^{2+}$ complex; which forms as a result of the imidazole polymer's ability to bind both fluorophore and fluorescence quencher $\left(\mathrm{Cu}^{2+}\right)$. Cyanide removes $\mathrm{Cu}^{2+}$ from these complexes; thereby "turning-on" sensor fluorescence. These sensors are water-soluble and have a detection limit of $\sim 2.5 \mu \mathrm{M}\left(\mathrm{CN}^{-}\right)$in water. Our ternary complex-based sensing approach also enables facile emission tuning; we demonstrate the convenient, synthesis-free preparation of blue and green-emitting sensors using distyrylbiphenyl and fluorescein fluorophores, respectively. Furthermore; these ternary complexes are easily immobilized using agarose to create cyanide-sensing hydrogels; which are then used in a simple; novel microdiffusion apparatus to achieve interference-free cyanide analysis of aqueous media. The present study provides an inexpensive approach for portable; interference-free cyanide detection.
\end{abstract}

Keywords: fluorescence; non-covalent; complex; sensor; turn-on; off-on; microdiffusion; cyanide; hydrogel; agarose

\section{Introduction}

An estimated 1.4 million tons of cyanide is produced annually for use in mining, metal processing, plastic and fiber production, tanning, cosmetics, pest control, pharmaceuticals and photography $[1,2]$. The transportation and widespread use of this highly toxic chemical poses a significant health risk to human beings. Smoke inhalation is another source of cyanide exposure and $\sim 3000-6000$ people are exposed to potentially lethal cyanide levels every year from fire smoke [3-7]. In addition, pathogen-mediated cyanogenesis has an acknowledged role in cystic fibrosis lung disease [8-12]. As a result, methods for rapid and sensitive cyanide detection have attracted much interest $[5,13]$.

Fluorescent sensors are an attractive option for cyanide detection, because they are easy to use and exhibit good sensitivity, specificity and response times. The two most common fluorescence-based cyanide sensors are chemodosimeters and metal-ion-displacement probes [13-15]. Chemodosimeters change their optical signal upon reaction with cyanide and are thus irreversible probes $[13,16]$. In contrast, sensors based on cyanide-mediated displacement of metal ions from ion-chelating fluorophores are reversible, but multistep synthesis is often required to produce the ion-chelating fluorophore [17-25], making the replication and implementation of such probes difficult for those without synthesis expertise. Thus, a simple, synthesis-free cyanide sensor construction would not only provide a more cost-effective solution, but also broaden both the range of users and the situations in which monitoring is possible (e.g., portable, on-the-go cyanide sensing in the field, in remote areas and by first responders). 
In this paper, we show that cyanide-sensing fluorophore-polymer-quencher (FPQ) complexes are easily prepared by mixing as-received, commercially available, fluorescent dye, dye-binding imidazole polymer and fluorescence quencher $\left(\mathrm{Cu}^{2+}\right)$. A distyrlbiphenyl fluorophore is used to produce a blue-emitting "turn-on" sensor that can detect as little as $\sim 2.5 \mu \mathrm{M}$ cyanide; well below lethal blood cyanide levels $(\sim 40 \mu \mathrm{M})[2,5,26]$ and the US Environmental Protection Agency's (EPA) maximum contaminant levels for cyanide in drinking water $(\sim 8 \mu \mathrm{M})$ [27]. Furthermore, the detection range of these sensors can be modified easily by controlling the relative proportion of quencher within the FPQ complex. We also introduce a sensor immobilization strategy using a biopolymer gel as well as a passive microdiffusion device assembled from off-the-shelf materials, namely, a glass vial and cotton fabric. In contrast with current passive microdiffusion devices [5,28,29], the proof-of-concept assay developed in this work does not need a special analysis cell and is significantly more portable and accident-proof because it traps cyanide in an immobilized cyanide-sensing gel instead of the traditionally used capture solutions. Finally, we demonstrate the versatility of the FPQ sensor platform by using a different fluorophore, fluorescein, to produce a green-emitting sensor. The sensors and assays reported herein represent new, broadly accessible methodologies for inexpensive cyanide analysis without the need for specialized chemical synthesis or device fabrication.

\section{Materials and Methods}

\subsection{Materials and Instruments}

All chemicals are commercially available and were used as received. Scheme 1 contains formula representations of all fluorophores and polymers used herein. Tinopal CBS-X (1) (88\% pure) was purchased from BASF. Pure disodium fluorescein (2) was obtained from Acros Organics. A $30 \mathrm{wt} \%$ solution of vinylimidazole/vinylpyrrolidone copolymer (3) (MW 70,000 g/mol) was obtained from BASF (Sokalan HP 56K).
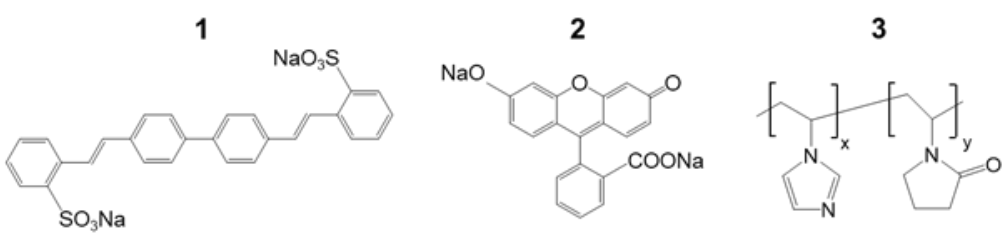

Scheme 1. Commercial fluorophores (1)-(2) and polymer (3) used in this work.

$\mathrm{CuCl}_{2} .2 \mathrm{H}_{2} \mathrm{O}, \mathrm{NaCN}, \mathrm{NaI}, \mathrm{NaSCN}, \mathrm{NaCl}, \mathrm{Na}_{2} \mathrm{~S} .9 \mathrm{H}_{2} \mathrm{O}, \mathrm{Na}_{2} \mathrm{CO}_{3}, \mathrm{NaNO}_{2}, \mathrm{NaNO}_{3}, \mathrm{NaHCO}_{3}$, $\mathrm{NH}_{4} \mathrm{OH}, \mathrm{CH}_{3} \mathrm{COOH}, \mathrm{C}_{2} \mathrm{H}_{3} \mathrm{O}_{2} \mathrm{Na} \cdot 3 \mathrm{H}_{2} \mathrm{O}, \mathrm{Na}_{2} \mathrm{SO}_{3}, \mathrm{Na}_{2} \mathrm{SO}_{4}, \mathrm{NaHSO}_{4} \cdot \mathrm{H}_{2} \mathrm{O}, \mathrm{NaHPO}_{4}, \mathrm{Na}_{3} \mathrm{PO}_{4} \cdot 12 \mathrm{H}_{2} \mathrm{O}$, $\mathrm{NaBr}, \mathrm{NaF}, \mathrm{HNO}_{3}, \mathrm{H}_{2} \mathrm{SO}_{4}, \mathrm{BSA}$, Ethanol, Acetone, Triton X-100 and HPLC grade Acetonitrile were purchased from Fisher Scientific. $\mathrm{Bi}\left(\mathrm{NO}_{3}\right)_{3} \cdot 5 \mathrm{H}_{2} \mathrm{O}$ was purchased from Sigma-Aldrich. $\mathrm{pH}=5$, MF254, alumina-backed TLC silica plates were purchased from Agela Technologies. Low gelling temperature agarose was purchased from Fisher Scientific. Bleached, brightened cotton was purchased from Testfabrics Inc. Twenty milliliter borosilicate glass scintillation vials were purchased from Fisher Scientific.

Fluorescence spectra were recorded using an Agilent Cary Eclipse fluorescence spectrophotometer, a Horiba Aqualog fluorimeter and a Synergy H1 Hybrid Multi-Mode Reader form BioTek. All emission spectra were recorded with an excitation wavelength of $350 \mathrm{~nm}$ for (1) and $480 \mathrm{~nm}$ for (2). One centimeter pathlength cuvettes were used for fluorimeter readings and Costar 96-well black polystyrene plates were used for fluorescence plate reader studies. FTIR analyses were performed using a Bruker Vertex 70 Hyperion 2000 Platinum ATR. Spectra were recorded at a resolution of $2 \mathrm{~cm}^{-1}$ with 32 scans. 


\subsection{Thin Layer Chromatography}

Amounts of $0.5 \mu \mathrm{L}$ of each of the following aqueous solutions were spotted on standard aluminum backed silica thin layer chromatography (TLC) plates and run side-by-side to generate the TLC data shown in Figure 1:

i) $\quad 0.8 \mathrm{mM} \mathbf{1}$ in deionized water (referred to as $\mathbf{1}$ in Figure $1 \mathrm{~b}$ ).

ii) $\quad 0.8 \mathrm{mM} 1+0.4 \mathrm{mM} 3$ in deionized water (referred to as $\mathbf{1}+3$ in Figure $1 \mathrm{~b}$ ).

iii) $0.8 \mathrm{mM} 1+0.4 \mathrm{mM} 3+16 \mathrm{mM} \mathrm{Cu}^{2+}+300 \mathrm{mM} \mathrm{CN}^{-}$in deionized water (referred to as $\mathbf{1}+3+\mathrm{Cu}^{2+}+\mathrm{CN}^{-}$in Figure $\left.1 \mathrm{~b}\right)$.

The solvent system comprised $25 \mathrm{wt} \%$ acetonitrile and $75 \mathrm{wt} \%$ deionized water.

(a)

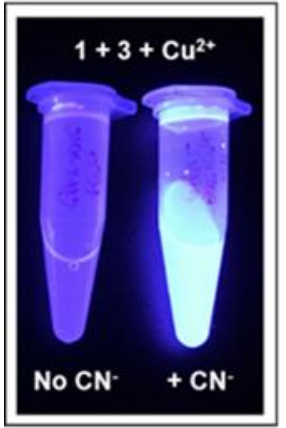

(d)

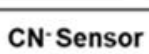
(OFF)

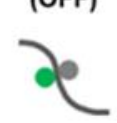

(b)
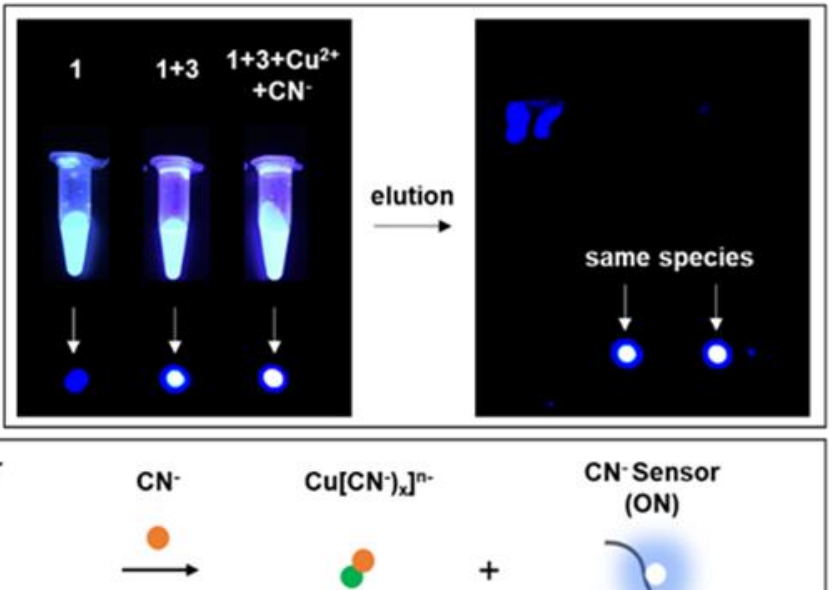

$\left.\mathrm{Cu}[\mathrm{CN}-)_{\mathbf{x}}\right]^{\mathrm{n}}$
CN-Sensor (ON)

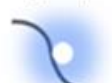

(c)

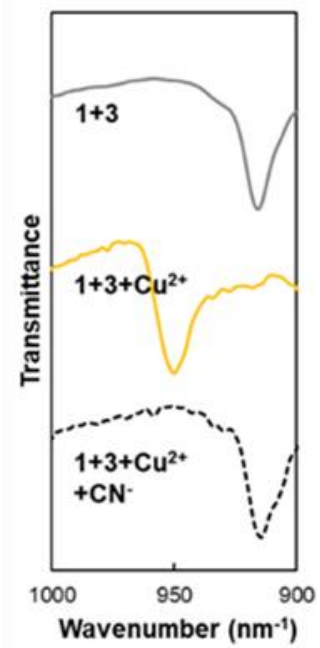

Figure 1. (a) Photograph of an aqueous mixture containing $0.8 \mathrm{mM} \mathrm{1}, 0.4 \mathrm{mM} 3$ and $16 \mathrm{mM} \mathrm{Cu}^{2+}$

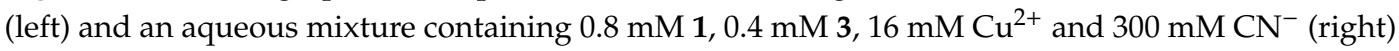
under UV illumination. (b) UV-illuminated $\left(\lambda_{\mathrm{EX}}=350 \mathrm{~nm}\right)$ spots of $0.8 \mathrm{mM} 1$ only, a $0.8 \mathrm{mM} 1+$ $0.4 \mathrm{mM} 3$ mixture, and a $0.8 \mathrm{mM} 1+0.4 \mathrm{mM} 3+16 \mathrm{mM} \mathrm{Cu}^{2+}+300 \mathrm{mM} \mathrm{CN}^{-}$mixture on a TLC plate, before (left) and after (right) elution with solvent. TLC solvent system: acetonitrile/water 25:75 (w/w). TLC plates with standard silica treatment and aluminium backing are used. (c) Mid-FTIR spectra in the low frequency region for a $\mathbf{1 + 3}$ complex (gray line), and a $\mathbf{1}+3+\mathbf{C u}^{2+}$ complex before (yellow line) and after (dashed black line) treatment with excess $\mathrm{CN}^{-}$. The $\mathbf{1}+\mathbf{3}$ complex has 2:1 (1:3) stoichiometry. The $\mathbf{1 + 3}+\mathbf{C u}^{2+}$ complex has 2:1:40 (1:3: $\left.\mathbf{C u}^{2+}\right)$ stoichiometry. (d) Schematic representation of the effect of $\mathrm{CN}^{-}$addition on $\mathbf{1}+3+\mathrm{Cu}^{2+}$ complexes.

\subsection{Attenuated Total Reflectance-Fourier Transform Infrared Studies}

Purification of the various complexes described herein followed the procedure of Fernandes et al. [30]. For $\mathbf{1 + 3}$ complexes, $3.25 \mathrm{~g}$ of a $\mathbf{1 + 3}$ mixture containing $0.8 \mathrm{mM}$ (1) and $0.4 \mathrm{mM}$ (3) was thoroughly mixed and sonicated with $125 \mathrm{~g}$ of a solvent system containing $50 \mathrm{~g}$ of ethyl acetate and $75 \mathrm{~g}$ of acetone, which resulted in selective precipitation of the $1+3$ complex. The resulting precipitate was washed, dried, and characterized using ATR-FTIR (referred to as $\mathbf{1 + 3}$ in Figure 1c).

For the preparation and purification of $\mathbf{1 + 3}+\mathbf{C} \mathbf{u}^{2+}$ complexes, $3.25 \mathrm{~g}$ of a $\mathbf{1 + 3}$ mixture containing $0.8 \mathrm{mM}(1)$ and $0.4 \mathrm{mM}(3)$ was thoroughly mixed and sonicated with $1 \mathrm{~mL}$ of $0.5 \mathrm{M} \mathrm{Cu}^{2+}$ (aqueous) to saturate the $1+3$ complex with $\mathrm{Cu}^{2+}$ ions. The resulting precipitate was washed, dried and characterized

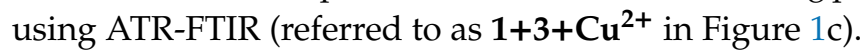

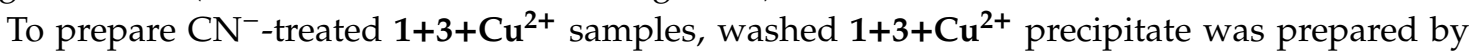
repeating the procedure above, dissolved in $1 \mathrm{~mL}$ of $0.5 \mathrm{M} \mathrm{CN}^{-}$(aqueous), dried and characterized

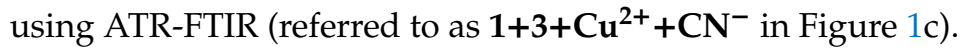




\section{Results and Discussion}

\subsection{Sensing Mechanism}

Our sensor is a quenched, non-fluorescent, aqueous mixture comprising fluorophore (1), 1-vinyl imidazole polymer (3) and $\mathrm{Cu}^{2+}$ in 2:1:40 stoichiometry (Figure 1a, left). Our recent work [30]

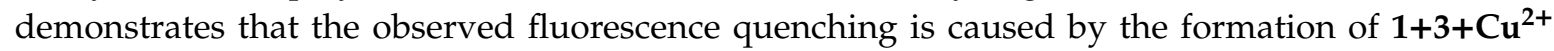
complexes; a direct result of the imidazole polymer's ability to bind both fluorophore and fluorescence quencher $\left(\mathrm{Cu}^{2+}\right)$. Our initial choice of 2:1:40 (1:3: $\left.\mathbf{C u}^{2+}\right)$ stoichiometry is to minimize the amount of unbound fluorophore and at the same time, to saturate the complex with $\mathrm{Cu}^{2+}[30]$, resulting in a fully quenched solution with minimal background fluorescence (Figure $1 \mathrm{a}$, left). Upon the addition of cyanide to $\mathbf{1 + 3}+\mathbf{C u}^{2+}$ complexes, we observe a significant increase in solution fluorescence (Figure 1a, right). Since $\mathrm{CN}^{-}$associates strongly with $\mathrm{Cu}^{2+}$ [31], a known fluorescence quencher [32,33], we suspect that the observed fluorescence recovery is caused by cyanide-induced removal or the displacement of $\mathrm{Cu}^{2+}$ from the $\mathbf{1 + 3}+\mathrm{Cu}^{2+}$ complex.

To confirm that cyanide removes $\mathrm{Cu}^{2+}$ from $\mathbf{1 + 3}+\mathbf{C u}^{2+}$ complexes, we run chromatograms for fluorophore (1) only, $\mathbf{1 + 3}$ mixtures and $\mathrm{CN}^{-}$-treated $\mathbf{1}+3+\mathrm{Cu}^{2+}$ mixtures side-by-side on the same TLC plate (Figure 1b). As reported previously [30], retention times for fluorophore (1) only and 1+3 mixtures differ significantly on account of spontaneous fluorophore-polymer complexation in $1+3$

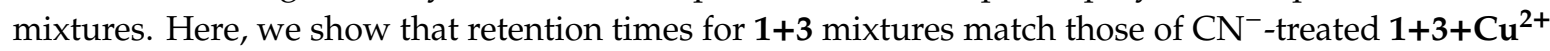
mixtures, which strongly suggests that high doses of $\mathrm{CN}^{-}$can remove all bound copper from $1+3+\mathrm{Cu}^{2+}$ complexes. The TLC data also show that $\mathrm{CN}^{-}$treatment does not displace fluorophore from the

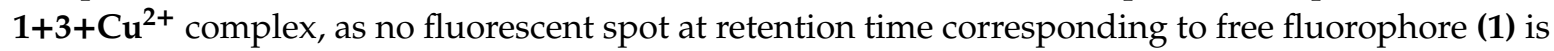
observed for $\mathrm{CN}^{-}$-treated $\mathbf{1}+3+\mathbf{C u}^{2+}$ samples. Additional evidence for $\mathrm{CN}^{-}$-mediated removal of bound copper from $\mathbf{1}+3+\mathbf{C u}^{2+}$ complexes comes from ATR-FTIR, where the effect of $\mathrm{CN}^{-}$exposure on the coordinate bonds between $\mathrm{Cu}^{2+}$ and the imidazole ligands present in $\mathbf{1 + 3}$ complexes is monitored (Figure 1c).

Mid-FTIR spectra (Figure 1c) show that exposure of $\mathbf{1 + 3}$ complexes to $\mathrm{Cu}^{2+}$ results in the disappearance of the band at $915 \mathrm{~cm}^{-1}$ and the occurrence of a band at $950 \mathrm{~cm}^{-1}$. For 1-vinyl imidazole polymers, this is a signature of replacement of imidazole- $\mathrm{H}_{2} \mathrm{O}$-imidazole bridged water with $\mathrm{Cu}^{2+}$ to from imidazole- $\mathrm{Cu}^{2+}$-imidazole complexes [34-36]. The Mid-FTIR spectra for $\mathrm{CN}^{-}$-treated $\mathbf{1 + 3 + C \mathbf { u } ^ { 2 + }}$ complexes shows a reverse effect, namely, the disappearance of the $950 \mathrm{~cm}^{-1}$ band and the recovery of the band at $915 \mathrm{~cm}^{-1}$. This shows that $\mathrm{CN}^{-}$treatment replaces the imidazole- $\mathrm{Cu}^{2+}$-imidazole coordinate bonds within the $\mathbf{1}+3+\mathbf{C u}^{2+}$ complexes with imidazole- $\mathrm{H}_{2} \mathrm{O}$-imidazole bonds, thus proving the cyanide-mediated displacement of $\mathrm{Cu}^{2+}$ from $\mathbf{1}+3+\mathrm{Cu}^{2+}$ complexes.

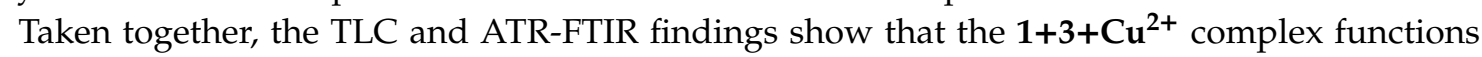
as a $\mathrm{Cu}^{2+}$-displacement-based fluorescence "turn-on" probe for cyanide (Figure 1d). Unlike other $\mathrm{Cu}^{2+}$-displacement-based cyanide probes [17-25], our sensor is assembled by one-step mixing of as-received commercial materials and is thus "synthesis-free". The cyanide sensor described in this paper would allow researchers to quickly assemble inexpensive cyanide probes without the need for

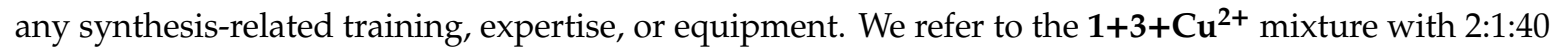
stoichiometry as sensor A.

\subsection{Sensing Performance and Sensitivity Optimization}

Emission spectra of sensor $\mathbf{A}$, recorded before and after $\mathrm{CN}^{-}$addition, show an increase in emission intensity with increasing $\mathrm{CN}^{-}$concentration, thus confirming that sensor $\mathbf{A}$ acts as a fluorescence "turn-on" probe for $\mathrm{CN}^{-}$(Figure 2a). Fluorescence recovery $\left(\mathrm{I} / \mathrm{I}_{\mathrm{b}}\right)$ for sensor $\mathbf{A}$, where $\mathrm{I}$ is sensor $\mathbf{A}^{\prime} \mathrm{s}$ peak emission intensity in the presence of $\mathrm{CN}^{-}$and $\mathrm{I}_{\mathrm{b}}$ is the background fluorescence from sensor $\mathbf{A}$ in the absence of $\mathrm{CN}^{-}$, is linear in the $10-20 \mu \mathrm{M} \mathrm{CN}^{-}$range and is complete upon exposure to $\sim 40 \mu \mathrm{M}$ $\mathrm{CN}^{-}$(Figure $2 \mathrm{~b}$ ). The detection limit of sensor $\mathrm{A}$ is therefore $\sim 10 \mu \mathrm{M}$, well below the lethal blood 
cyanide levels in smoke inhalation victims $(\sim 40 \mu \mathrm{M})$ [2,5,26], making sensor A potentially useful for the detection of harmful levels of $\mathrm{CN}^{-}$in the blood of smoke inhalation victims and firefighters.

(a)

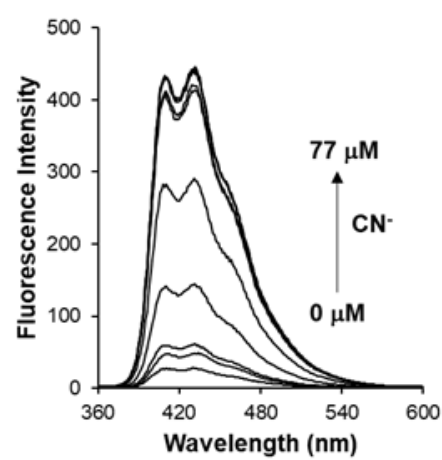

(b)

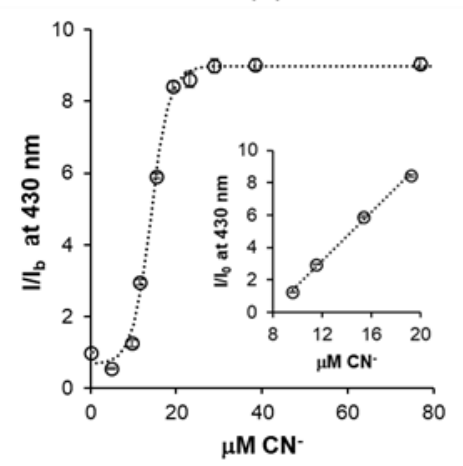

Figure 2. (a) Fluorescence emission spectra of $0.1 \mu \mathrm{M}$ sensor A (a $0.2 \mu \mathrm{M} 1+0.1 \mu \mathrm{M} 3+4 \mu \mathrm{M}$ $\mathrm{Cu}^{2+}$ mixture) upon addition of increasing concentrations of $\mathrm{CN}^{-}(0-77 \mu \mathrm{M})$ in aqueous solution. (b) Fluorescence recovery $\left(\mathrm{I} / \mathrm{I}_{\mathrm{b}}\right)$ of $0.1 \mu \mathrm{M}$ sensor $\mathbf{A}$ (open circles) upon addition of $\mathrm{CN}^{-}$. The dashed line is a sigmoidal fit and is intended to guide the eye. The insert is the recovery plot in the linear dose response region. For all studies reported in Figure 2, error bars represent three standard deviations, the solvent used is $0.5 \mathrm{wt} \%$ Triton $\mathrm{X}-100$ in deionized water, and $\lambda_{\mathrm{EX}}=350 \mathrm{~nm}$. Sensor $\mathbf{A}$ is a $\mathbf{1}+\mathbf{3}+\mathbf{C u}^{2+}$ complex with 2:1:40 (1:3: $\left.\mathrm{Cu}^{2+}\right)$ stoichiometry.

Efforts to improve sensor A's performance involve adjusting the formulation of the $\mathbf{1}+3+\mathrm{Cu}^{2+}$ complex, as summarized in Figure 3a. We observe that (i) the sensor's detection limit can be substantially improved by reducing the relative proportion of quencher $\left(\mathrm{Cu}^{2+}\right)$ in the $\mathbf{1 + 3 +} \mathrm{Cu}^{2+}$ mixture, and (ii) 2:1:24 $\left(1: 3: \mathrm{Cu}^{2+}\right)$ stoichiometry represents the limit beyond which no additional sensitivity is gained by lowering relative $\mathrm{Cu}^{2+}$ levels. As expected, these sensitivity improvements come at the cost of compromised background fluorescence, but the effect is minimal for mixtures with 2:1:24 (1:3:Cu$\left.{ }^{2+}\right)$ stoichiometry and only becomes pronounced in 2:1:16 (1:3: $\left.\mathbf{C u}^{2+}\right)$ mixtures, where we see a two-fold increase (Figure 3b).

(a)

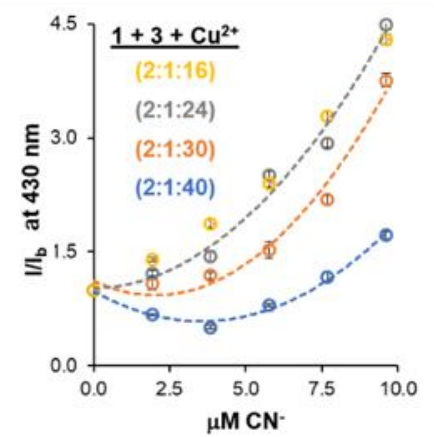

(b)

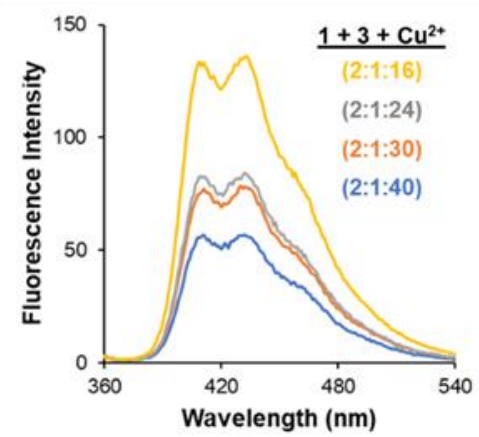

(c)

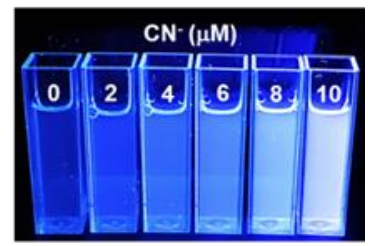

Figure 3. (a) Fluorescence recovery $\left(\mathrm{I} / \mathrm{I}_{\mathrm{b}}\right)$ of aqueous mixtures containing $0.2 \mu \mathrm{M} 1+0.1 \mu \mathrm{M} 3+\mathrm{X} \mu \mathrm{M}$ $\mathrm{Cu}^{2+}$ upon addition of increasing concentrations of $\mathrm{CN}^{-}(0-10 \mu \mathrm{M}) ; \mathrm{X}=1.6 \mu \mathrm{M}$ (yellow circles), $2.4 \mu \mathrm{M}$ (gray circles), $3 \mu \mathrm{M}$ (orange circles) and $4 \mu \mathrm{M}$ (blue circles) $\mathrm{Cu}^{2+}$ respectively; dashed lines are guides to the eye. (b) Fluorescence emission spectra of aqueous mixtures containing $0.2 \mu \mathrm{M} 1+0.1 \mu \mathrm{M} 3+\mathrm{X}$ $\mu \mathrm{M} \mathrm{Cu}^{2+} ; \mathrm{X}=1.6 \mu \mathrm{M}$ (yellow curve), $2.4 \mu \mathrm{M}$ (gray curve), $3 \mu \mathrm{M}$ (orange curve) and $4 \mu \mathrm{M}$ (blue curve) $\mathrm{Cu}^{2+}$ respectively. (c) Photograph of aqueous mixtures containing $0.2 \mu \mathrm{M} 1+0.1 \mu \mathrm{M} 3+2.4 \mu \mathrm{M} \mathrm{Cu}^{2+}$ as a function of increasing $\mathrm{CN}^{-}$levels; taken under $\mathrm{UV}$ illumination $\left(\lambda_{\mathrm{EX}}=350 \mathrm{~nm}\right)$. For all studies reported in Figure 3, error bars represent three standard deviations, the solvent used is $0.5 \mathrm{wt} \%$ Triton $\mathrm{X}-100$ in deionized water, and $\lambda_{\mathrm{EX}}=350 \mathrm{~nm}$. 
We therefore find 2:1:24 (1:3: $\left.\mathbf{C u}^{2+}\right)$ stoichiometry to be optimal; this ternary mixture remains non-fluorescent or "off" in the absence of cyanide (Figure 3b), but (i) enables the quantitation of $<10 \mu \mathrm{M} \mathrm{CN}^{-}$with an analytical detection limit of $\sim 2.5 \mu \mathrm{M} \mathrm{CN}^{-}$(See Supplementary Information) and (ii) exhibits a visually discernable fluorescence recovery at $\mathrm{CN}^{-}$levels as low as $5 \mu \mathrm{M}$ (Figure 3c). Since the EPA has set the maximum contaminant level for cyanide in drinking water at $\sim 8 \mathrm{M}$ [27], our optimized sensor could potentially serve as a candidate for the fluorogenic, naked-eye detection of harmful levels of $\mathrm{CN}^{-}$in drinking water.

The tunability of the $\mathrm{CN}^{-}$detection range and limit can be understood by considering the fluorescence intensity as a function of bound $\mathrm{Cu}^{2+}$ within the ternary complex. In the absence of $\mathrm{CN}^{-}$, fluorescence quenching by $\mathrm{Cu}^{2+}$ is described by a Stern-Volmer plot, $\mathrm{I} / \mathrm{I}_{0}=\left(1+\mathrm{K}_{\mathrm{sv}}\left[\mathrm{Cu}^{2+}\right]\right)^{-1}$, where $\mathrm{I}_{0}$ and $\mathrm{I}$ are the peak fluorescence intensities for $\mathbf{1 + 3}$ mixtures before and after addition of $\mathrm{Cu}^{2+}$ (quenching constant, $\mathrm{K}_{\mathrm{sv}} \sim 1.68 \mu \mathrm{M}^{-1}$; see Supplementary Information). Thus, the expected fluorescence recovery upon $\mathrm{Cu}^{2+}$ removal from $\mathbf{1}+3+\mathbf{C u}^{2+}$ complexes can be described by this very curve, as represented by the fluorescence intensity as a function of $\mathbf{1 + 3}$-bound $\mathrm{Cu}^{2+}$ levels (Figure 4, dotted line). From our previous work [30], we know that each $\mathbf{1}+3$ complex binds $\sim 30 \mathrm{Cu}^{2+}$ ions. Therefore, by assuming that (i) free $\mathrm{Cu}^{2+}$ forms $\left[\mathrm{Cu}(\mathrm{CN})_{4}\right]^{3-}$ complexes [18] and (ii) $\mathrm{CN}^{-}$-induced $\mathrm{Cu}^{2+}$ displacement from $\mathbf{1 + 3 + \mathbf { C u } ^ { 2 + }}$ complexes involves formation of $\left[\mathrm{Cu}(\mathrm{CN})_{\mathrm{x}}\right]^{1-\mathrm{x}}(\mathrm{x}=4 \sim 6)$ complexes, superposition of all dose-response curves shown in Figure 3 a onto a single master-curve is achieved (Figure 4). This superposition is further confirmation that $\mathbf{1 + 3}+\mathrm{Cu}^{2+}$ complexes function as $\mathrm{Cu}^{2+}$-displacement-based fluorescence "turn-on" probes for cyanide.

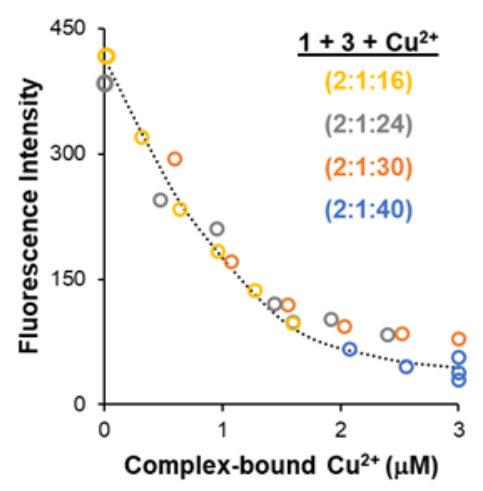

Figure 4. Superposition of $\mathrm{CN}^{-}$dose response curves from Figure $3 a$, obtained by plotting fluorescence $\left(\lambda_{\mathrm{EX}}=350 \mathrm{~nm} ; \lambda_{\mathrm{EM}}=430 \mathrm{~nm}\right)$ as function of bound $\mathrm{Cu}^{2+}$ within the ternary $\left(\mathbf{1}+\mathbf{3}+\mathrm{Cu}^{2+}\right)$ complex; the dotted line represents the expected fluorescence response upon $\mathrm{Cu}^{2+}$ removal from the ternary

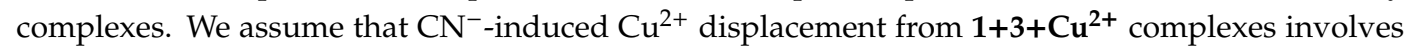
formation of $\left[\mathrm{Cu}(\mathrm{CN})_{\mathrm{x}}\right]^{1-\mathrm{x}}$ complexes; $\mathrm{x}=4$ (blue, orange and gray circles) and 6 (yellow circles).

\subsection{Overcoming Interference}

Figure 5 depicts the fluorescence recovery $\left(\mathrm{I} / \mathrm{I}_{\mathrm{b}}\right)$ of sensor $\mathbf{A}$ upon addition of various anions and shows that species with high $\mathrm{Cu}^{2+}$ affinity (e.g., $\mathrm{S}^{2-}$ ) $[37,38]$ cause significant interference. Since complex biological fluids such as wound exudate, sputum and blood contain chemical interferents such as $\mathrm{H}_{2} \mathrm{~S}$ [39-41], cytokines [42] and bacterial secretions [43] and cause optical interference due to their color and opacity [42], practical implementation of sensor A requires isolation of cyanide from sources of interference. Herein, we introduce a simple microdiffusion device that effectively separates cyanide from non-volatile interferents and enables relatively rapid ( $30 \mathrm{~min})$, interference-free detection of cyanide using two inexpensive, off-the-shelf materials, namely, a glass vial and a cotton fabric (Figure 6). 


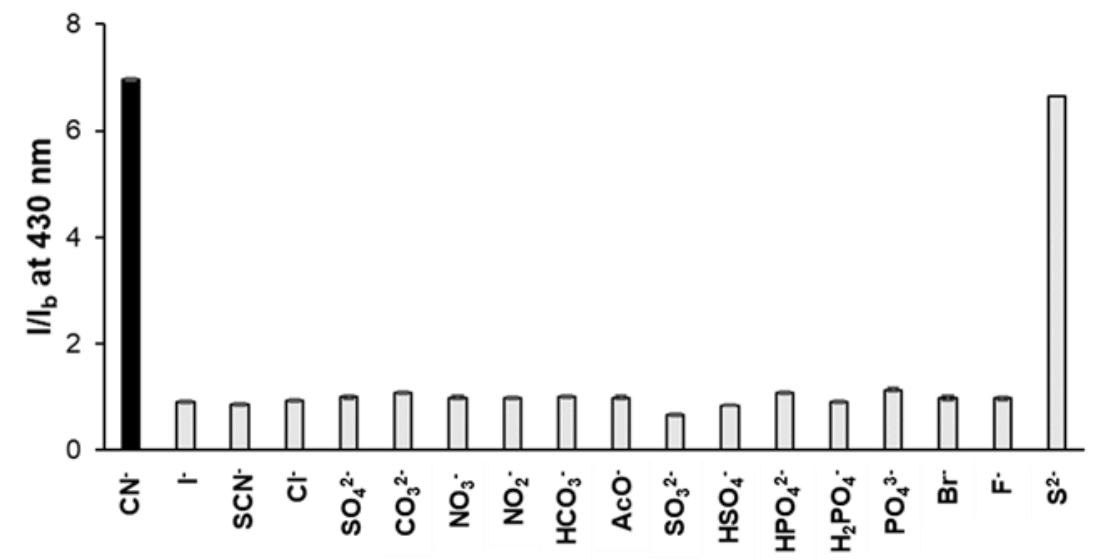

Figure 5. Fluorescence recovery $\left(\mathrm{I} / \mathrm{I}_{\mathrm{b}}\right)$ for $0.1 \mu \mathrm{M}$ sensor $\mathbf{A}\left(\mathrm{a} 0.2 \mu \mathrm{M} 1+0.1 \mu \mathrm{M} 3+4 \mu \mathrm{M} \mathrm{Cu}^{2+}\right.$ mixture $)$ in the presence of $25 \mu \mathrm{M}$ of various anions; the solvent used is $0.5 \mathrm{wt} \%$ Triton X-100 in deionized water and $\lambda_{\mathrm{EX}}=350 \mathrm{~nm}$.

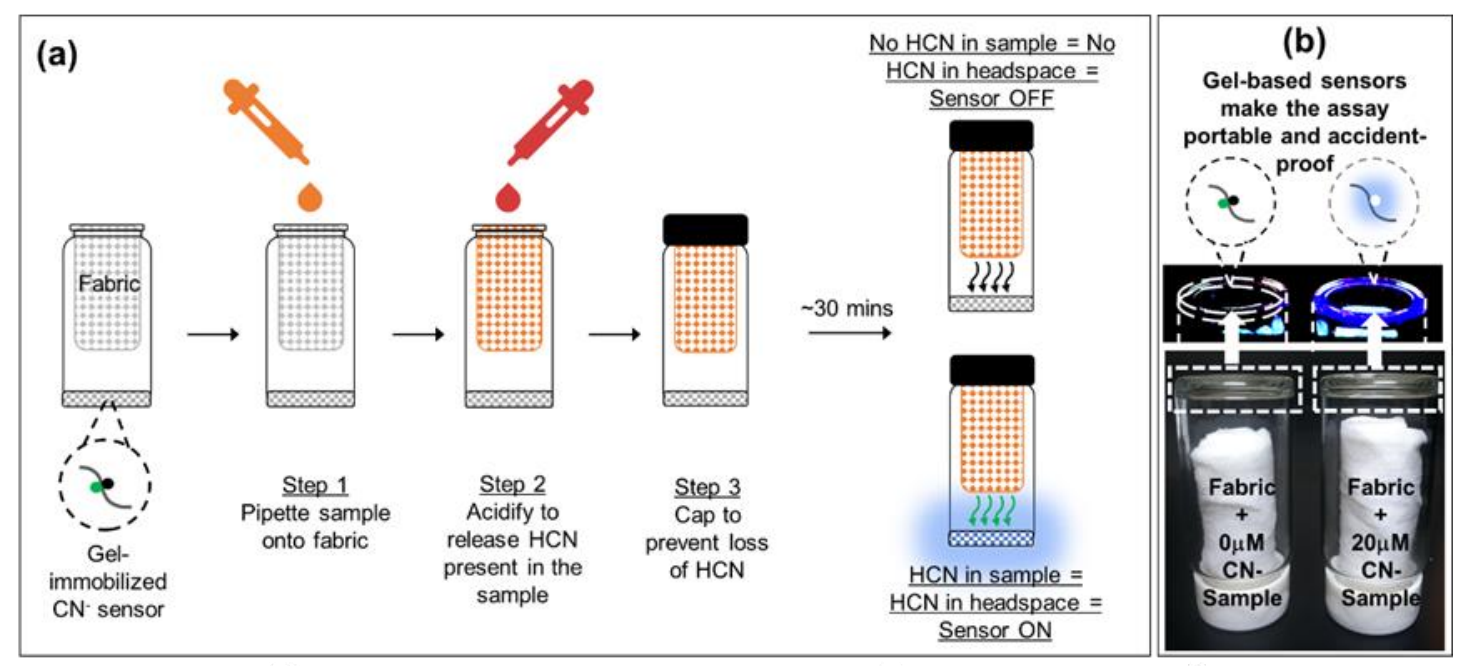

Figure 6. (a) Schematic illustration of the microdiffusion assay introduced in this work for separating cyanide from interfering species present withing the sample. (b) Photographs of inverted assay vials demonstrating how sensor immobilization within a gel makes the assay resistant to disturbances. The acidification reagent comprises $1 \mathrm{~g} / \mathrm{L} \mathrm{Bi}\left(\mathrm{NO}_{3}\right)_{3} .5 \mathrm{H}_{2} \mathrm{O}$ in $0.55 \mathrm{M} \mathrm{H}_{2} \mathrm{SO}_{4}$. All pictures are taken $30 \mathrm{~min}$ after acidification under UV illumination $\left(\lambda_{\mathrm{EX}}=350 \mathrm{~nm}\right)$. The gel-immobilized sensor comprises $0.5 \%$ agar, $0.26 \mu \mathrm{M}$ fluorophore, $0.75 \mu \mathrm{M}$ polymer and $2 \mu \mathrm{M} \mathrm{Cu}{ }^{2}$ in DI water.

To assemble the microdiffusion device, a warm $\left(50{ }^{\circ} \mathrm{C}\right)$ sensor A solution containing $0.5 \mathrm{wt} \%$ dissolved agar is pipetted into the bottom of a vial which, upon-cooling, produces a cyanide-sensing hydrogel. These gel-based sensors stay affixed to the bottom of the vial even when the vial is inverted (Figure 6b), thus making the device portable and accident-proof. Next, (i) the mouth of the vial is plugged with cotton fabric, (ii) the fabric is sequentially wet with sample and acid, which converts non-volatile $\mathrm{CN}^{-}$present in the sample into volatile $\mathrm{HCN}$ and (iii) the vial is capped to prevent loss of HCN. Cyanide released into the vial headspace eventually dissolves in the hydrogel sensor located at the bottom of the device and "turns-on" fluorescence. This simple, qualitative assay can detect as little as $20 \mu \mathrm{M} \mathrm{CN}^{-}$in $3 \mathrm{~mL}$ of sample (Figure $7 \mathrm{a}$ ). 

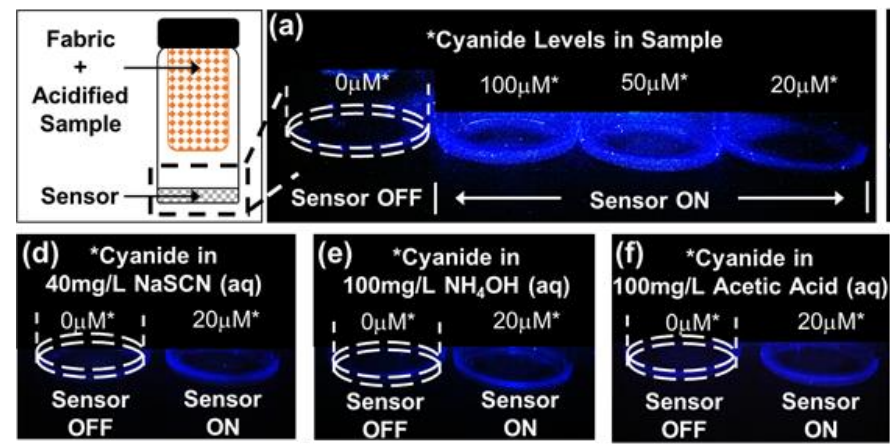
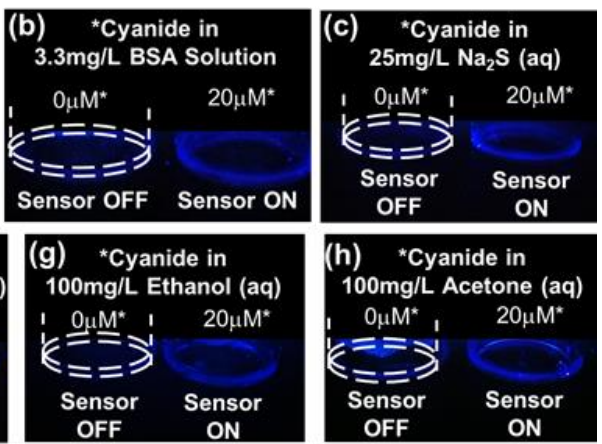

Figure 7. (a) Photographs, taken under UV illumination, show that the sensor, located at the bottom of the assay vial, while never in contact with the sample, produces a visually discernible response for samples containing $\geq 20 \mu \mathrm{M}$ cyanide. (b) Photographs, taken under UV illumination, show that the assay overcomes interference from non-volatile species in the sample as illustrated using BSA solutions. (c)-(h) Photographs, taken under UV illumination, show that inclusion of bismuth nitrate in the acidification reagent overcomes sulfide interference and does not produce false positives with other common volatile species expected in biological samples. The acidification reagent comprises $1 \mathrm{~g} / \mathrm{L}$ $\mathrm{Bi}\left(\mathrm{NO}_{3}\right)_{3} .5 \mathrm{H}_{2} \mathrm{O}$ in $0.55 \mathrm{M} \mathrm{H}_{2} \mathrm{SO}_{4}$. All pictures are taken $30 \mathrm{~min}$ after acidification under $\mathrm{UV}$ illumination $\left(\lambda_{\mathrm{EX}}=350 \mathrm{~nm}\right)$. The gel-immobilized sensor used comprises $0.5 \%$ agar, $0.26 \mu \mathrm{M}$ fluorophore, $0.75 \mu \mathrm{M}$ polymer and $2 \mu \mathrm{M} \mathrm{Cu}^{2}$ in DI water.

The fabric not only absorbs the sample and isolates it from the sensor, but also promotes evaporation of volatile compounds contained within the sample. In doing so, the fabric separates cyanide from non-volatile interferents such as proteins, siderophores and colored species present in the sample. Validation of this approach is provided in Figure $7 \mathrm{~b}$, where the assay is used to achieve interference-free cyanide analysis of a solution of serum albumin, a common, non-volatile, $\mathrm{Cu}^{2+}$-binding interferent found in blood (HSA level in blood $\sim 3.3 \mathrm{mg} / \mathrm{mL}$ ).

A number of volatile compounds including organic acids, thiocyanic acid, alcohols, ketones, sulfides, and ammonia are expected to be released into the headspace of the apparatus shown in Figure 6 upon the acidification of biological matrices such as wound exudate, sputum or blood [5,44-48]. $\mathrm{H}_{2} \mathrm{~S}$ is of particular concern because of the high affinity of sulfide ${ }^{19}$ for $\mathrm{Cu}^{2+}$ (Figure 5) [14,49-51]. We show that sulfide interference is removed by dissolving bismuth nitrate in the acidification reagent (Figure 7c); bismuth reacts with sulfide contained in the sample to form insoluble bismuth sulfide [52]. Our preliminary tests using other representative volatile species (Figure $7 \mathrm{~d}-\mathrm{h}$ ) at levels expected in biological matrices, show no evidence of interference and suggest that the simple microdiffusion assay introduced in this work could be developed into a portable device for interference-free cyanide detection in drinking water, wound exudate, sputum and blood.

The microdiffusion device described in this work shares a feature common to all passive microdiffusion devices, namely, design simplicity. It also provides analysis times comparable to the fastest passive microdiffusion-based assays $[5,28,29]$, However, unlike the classical Conway passive microdiffusion device and its variants, (i) our apparatus does not require a special analysis cell and is assembled using just fabric and a glass vial, and (ii) our device captures cyanide in an immobilized cyanide-sensing gel instead of a capture solution and is therefore more resistant to disturbances; making it more portable and accident-proof. On the whole, the proof-of-concept assay introduced herein represents a valuable new technique for rapid, interference-free, field-portable cyanide detection.

\subsection{Cyanide Sensing Hydrogels}

Figure 8a compares the cyanide-induced fluorescence recovery of sensor $\mathbf{A}$ in solution (open circles) with that of sensor $\mathbf{A}$ within an agarose hydrogel (open squares) and shows that gel immobilization increases sensor A's cyanide sensitivity. As discussed earlier (Figure 3a), the cyanide sensitivity of 
$\mathbf{1 + 3 +} \mathbf{C u}^{2+}$ complexes like sensor $\mathbf{A}$ can be improved by lowering relative $\mathrm{Cu}^{2+}$ levels within the complex. Since D-galactose, a component of the agarobiose repeat unit that makes up agarose, is known to coordinate with $\mathrm{Cu}$ (II) [53-57], we hypothesize that agarose displaces a fraction of the bound $\mathrm{Cu}^{2+}$ present within sensor $\mathbf{A}$, thereby decreasing the relative $\mathrm{Cu}^{2+}$ level within the $1+3+\mathrm{Cu}^{2+}$ complex, which improves its sensitivity to lower doses of cyanide.

To confirm that agarose removes $\mathrm{Cu}^{2+}$ from $\mathbf{1}+3+\mathrm{Cu}^{2+}$ complexes, we record fluorescence emission spectra of agarose only, sensor $\mathbf{A}\left(\mathrm{a} \mathbf{1}+3+\mathbf{C u}^{2+}\right.$ complex $)$ only, and a mixture of agarose and sensor A (Figure 8b). Addition of non-fluorescent agarose to sensor A results in a small but measurable increase in solution fluorescence which supports the hypothesis that agarose removes a fraction of the fluorescence quencher $\left(\mathrm{Cu}^{2+}\right)$ from sensor $\mathbf{A}$. It is unlikely that agarose removes the anionic fluorophore (1) from $1+3+\mathrm{Cu}^{2+}$ complexes, since the active dye-binding groups on agarose, namely, the pendant hydroxyl groups on D-galactose [58,59], are ineffective at binding anionic dyes; a reason why agarose has been investigated as an absorbent for cationic dyes [59-62], but is not used for removal of anionic dyes from water.

Titration studies (Figure 8a) reveal that the cyanide dose-response curve for a solution

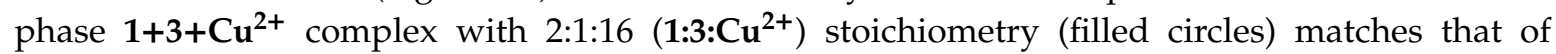

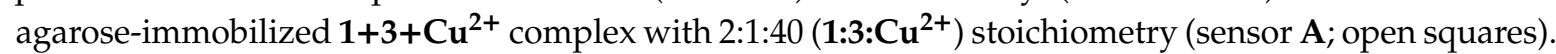
This means that when $0.1 \mu \mathrm{M}$ sensor $\mathbf{A}\left(\mathrm{a} 0.2 \mu \mathrm{M} 1+0.1 \mu \mathrm{M} 3+4 \mu \mathrm{MCu}^{2+}\right.$ mixture $)$ is immobilized inside $50 \mu \mathrm{M}$ of agarose, the agarose removes $\sim 2.4 \mu \mathrm{M} \mathrm{Cu}^{2+}$ from the sensor, implying that twenty agarose molecules are required to displace one $\mathrm{Cu}^{2+}$ ion from the $\mathrm{Cu}^{2+}$-chelating imidazole groups present in sensor $\mathbf{A}$. This result is supported by studies documenting the relatively poor $\mathrm{Cu}^{2+}$ complexation properties of carbohydrates such as D-galactose $[53,55-57]$ in comparison with other biological ligands such as imidazole [35,36,63-65]. It is this relative inertness of agarose to $\mathrm{Cu}^{2+}$, however, that makes it an excellent candidate for producing cyanide sensing hydrogels (Figure 8c) without destroying the sensor (a $\mathbf{1}+3+\mathrm{Cu}^{2+}$ complex).

(a)

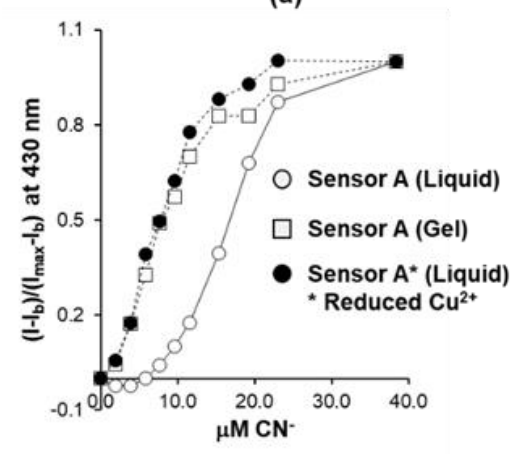

(b)

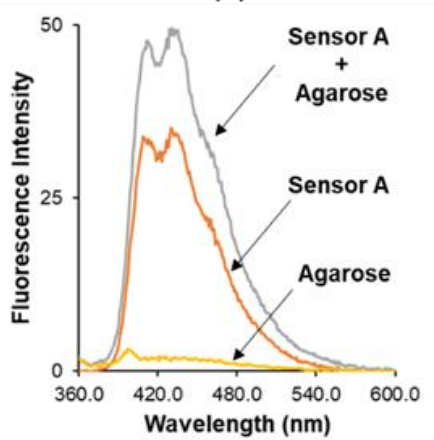

(c)

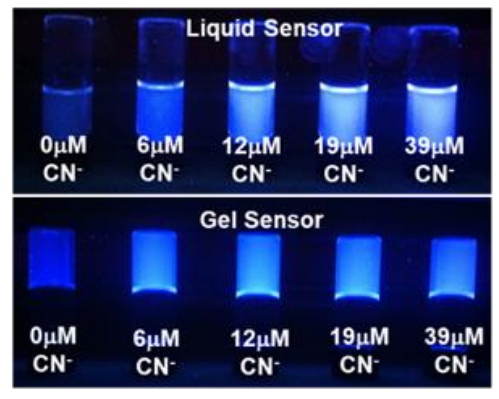

Figure 8. (a) Normalized fluorescence recovery of a $0.2 \mu \mathrm{M} 1+0.1 \mu \mathrm{M} 3+4 \mu \mathrm{M} \mathrm{Cu}{ }^{2+}$ liquid mixture (or $0.1 \mu \mathrm{M}$ sensor A-liquid) (open circles), a $0.2 \mu \mathrm{M} 1+0.1 \mu \mathrm{M} 3+4 \mu \mathrm{M} \mathrm{Cu}^{2+}+0.5 \mathrm{wt} \%$ agarose gel mixture (or $0.1 \mu \mathrm{M}$ sensor A-gel) (open squares) and a $0.2 \mu \mathrm{M} 1+0.1 \mu \mathrm{M} 3+1.6 \mu \mathrm{M}$ $\mathrm{Cu}^{2+}$ liquid mixture (or $0.1 \mu \mathrm{M}$ sensor A-reduced $\mathrm{Cu}^{2+}$-liquid) (filled circles), upon addition of $\mathrm{CN}^{-}$ $\left(\lambda_{\mathrm{EX}}=350 \mathrm{~nm}\right)$. (b) Fluorescence emission spectra $\left(\lambda_{\mathrm{EX}}=350 \mathrm{~nm} ; \mathrm{T}=40^{\circ} \mathrm{C}\right)$ of aqueous mixtures containing $0.5 \mathrm{wt} \%$ agarose only (yellow curve), $0.2 \mu \mathrm{M} \mathbf{1}+0.1 \mu \mathrm{M} 3+4 \mu \mathrm{M} \mathrm{Cu}^{2+}$ (or $0.1 \mu \mathrm{M}$ sensor A) only (orange curve), and an aqueous mixture containing $0.1 \mu \mathrm{M}$ sensor $\mathbf{A}$ and $0.5 \mathrm{wt} \%$ agarose (grey curve). (c) Photographs of $\mathrm{CN}^{-}$-induced fluorescence response of liquid sensor A-reduced $\mathrm{Cu}^{2+}$ or sensor $\mathbf{A}^{*}$ (top) and gel-immobilized sensor $\mathbf{A}$ (bottom) taken under UV illumination $\left(\lambda_{\mathrm{EX}}=350 \mathrm{~nm}\right)$; vial inversion demonstrates gel-immobilization.

\subsection{Emission Tuning}

Modifying sensor emission involves simply replacing the fluorophore component of the ternary fluorophore-polymer-quencher complex. To transform sensor $\mathbf{A}$ into a green-emitter, we replace the 
distyrylbiphenyl fluorophore (1) with green-emitting disodium fluorescein (2). Figure 9 confirms that

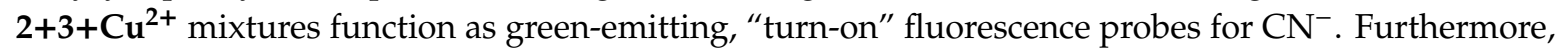
both blue $\left(\mathbf{1}+3+\mathbf{C u}^{2+}\right)$ and green $\left(2+3+\mathbf{C u}^{2+}\right)$ complexes show similar cyanide sensitivity and linear dose-response ranges (Figure $9 b, c$ ). Thus, in addition to simplifying sensor construction, the approach described in this paper also enables facile tuning of sensor emission colour without compromising cyanide sensitivity.

(a)

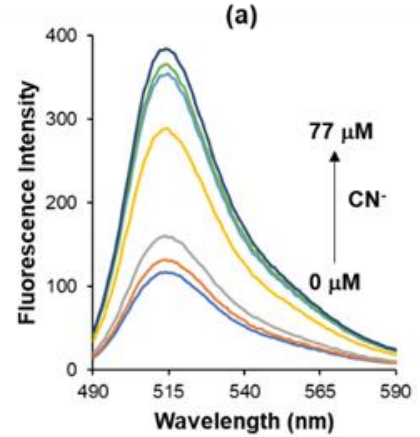

(b)

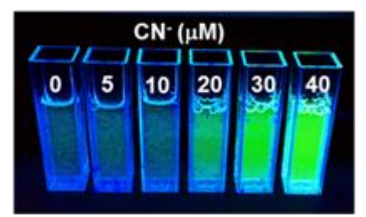

(c)

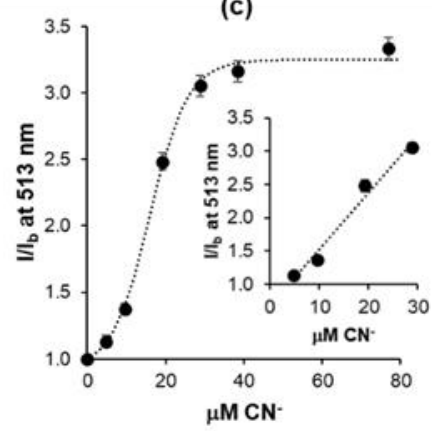

Figure 9. (a) Fluorescence emission spectra of a $0.2 \mu \mathrm{M} 2+0.1 \mu \mathrm{M} 3+16 \mu \mathrm{M} \mathrm{Cu}^{2+}$ mixture upon addition of increasing concentrations of $\mathrm{CN}^{-}(0-77 \mu \mathrm{M})$ in aqueous solution. (b) Photograph of aqueous mixtures containing $0.2 \mu \mathrm{M} 1+0.1 \mu \mathrm{M} 3+16 \mu \mathrm{M} \mathrm{Cu}^{2+}$ as a function of increasing $\mathrm{CN}^{-}$levels. (c) Fluorescence recovery $\left(\mathrm{I} / \mathrm{I}_{\mathrm{b}}\right)$ of a $0.2 \mu \mathrm{M} 1+0.1 \mu \mathrm{M} 3+16 \mu \mathrm{M} \mathrm{Cu}^{2+}$ mixture upon addition of $\mathrm{CN}^{-}$. For all studies reported in Figure 5, error bars represent three standard deviations, the solvent used is $0.5 \mathrm{wt} \%$ Triton $\mathrm{X}-100$ in deionized water, and $\lambda_{\mathrm{EX}}=480 \mathrm{~nm}$.

\section{Conclusions}

We combined three inexpensive commercial materials—namely fluorescent dye, 1-vinyl imidazole polymer and cupric chloride-to produce sensitive and selective "off-on" fluorescence sensors for $\mathrm{CN}^{-}$. The key cyanide-sensing species is a non-fluorescent fluorophore-polymer-Cu ${ }^{2+}$ complex, which forms as a result of the imidazole polymer's ability to bind both fluorophore and fluorescence quencher $\left(\mathrm{Cu}^{2+}\right) . \mathrm{CN}^{-}$removes or displaces $\mathrm{Cu}^{2+}$ from these complexes, thus "switching-on" sensor fluorescence. Our optimized sensors have analytical $(2.5 \mu \mathrm{M})$ as well as naked eye $(5 \mu \mathrm{M})$ detection limits that make them good candidates for the cyanide monitoring of drinking water as well as detection of harmful cyanide levels in the blood of smoke inhalation victims. Unlike other $\mathrm{Cu}^{2+}$ displacement-based cyanide probes, our sensor is assembled by one-step mixing of as-received commercial materials and is thus "synthesis-free". Our approach also enables the facile tuning of sensor emission color without compromising cyanide sensitivity. Finally, we used a glass vial, fabric and an agarose-immobilized sensor to assemble a simple, inexpensive, off-the-shelf microdiffusion apparatus that provides interference-free, qualitative cyanide analysis ( $20 \mu \mathrm{M}$ detection limit). Unlike other microdiffusion devices, our apparatus does not require a special analysis cell and is more portable and accident-proof because it captures cyanide in an immobilized, disturbance-resistant $\mathrm{CN}^{-}$-sensing gel instead of a capture solution. The cyanide sensors, formulations and microdiffusion apparatus described in this paper would allow researchers to quickly assemble inexpensive cyanide assays without the need for any synthesis-related training, expertise or equipment.

Supplementary Materials: The following are available online at http://www.mdpi.com/1424-8220/20/16/4488/s1, Figure S1: Estimating the quenching constant of $\mathbf{1}+3+\mathrm{Cu}^{2+}$ complexes, Figure S2: Analytical detection limit of optimized, $\mathrm{CN}^{-}$sensing, $\mathbf{1}+3+\mathrm{Cu}^{2+}$ complex.

Author Contributions: Conceptualization, G.E.F.; methodology, G.E.F. and Y.-W.C.; formal analysis, G.E.F. and Y.-W.C.; data curation, G.E.F., Y.-W.C., A.S. and S.T.; writing-original draft preparation, G.E.F. and Y.-W.C.; writing-review and editing, G.E.F. and Y.-W.C. All authors have read and agreed to the published version of the manuscript.

Funding: This research received no external funding. 
Acknowledgments: We thank Harvinder Gill and Danny Reible for fluorimeter access. Gregory Fernandes acknowledges support from New Faculty Startup Funds from Texas Tech University. Akash Sharma was supported by the Texas Tech University Center for Active Learning and Undergraduate Engagement Program.

Conflicts of Interest: The authors declare no conflict of interest.

\section{References}

1. Mudder, T.I.; Botz, M.M. Cyanide and Society: A Critical Review. Eur. J. Miner. Process. Environ. Prot. 2004, 4, 62-74.

2. Agency for Toxic Substances and Disease Registry (ATSDR). Toxicological Profile for Cyanide; U.S. Department of Health and Human Services, Public Health Service: Atlanta, GA, USA, 2006.

3. Alarie, Y. Toxicity of fire smoke. Crit. Rev. Toxicol. 2002, 32, 259-289. [CrossRef] [PubMed]

4. Lawson-Smith, P.; Jansen, E.C.; Hyldegaard, O. Cyanide intoxication as part of smoke inhalation-A review on diagnosis and treatment from the emergency perspective. Scand. J. Trauma Resusc. Emerg. Med. 2011, 19, 5. [CrossRef] [PubMed]

5. Jackson, R.; Logue, B.A. A review of rapid and field-portable analytical techniques for the diagnosis of cyanide exposure. Anal. Chim. Acta 2017, 960, 18-39. [CrossRef]

6. Stamyr, K.; Thelander, G.; Ernstgård, L.; Ahlner, J.; Johanson, G. Swedish forensic data 1992-2009 suggest hydrogen cyanide as an important cause of death in fire victims. Inhal. Toxicol. 2012, 24, 194-199. [CrossRef]

7. Yeoh, M.J.; Braitberg, G. Carbon monoxide and cyanide poisoning in fire related deaths in Victoria, Australia. J. Toxicol. Clin. Toxicol. 2004, 42, 855-863. [CrossRef]

8. Ryall, B.; Davies, J.C.; Wilson, R.; Shoemark, A.; Williams, H.D. Pseudomonas aeruginosa, cyanide accumulation and lung function in CF and non-CF bronchiectasis patients. Eur. Respir. J. 2008, 32, 740-747. [CrossRef]

9. Ryall, B.; Lee, X.Y.; Zlosnik, J.E.A.; Hoshino, S.; Williams, H.D. Bacteria of the Burkholderia cepacia complex are cyanogenic under biofilm and colonial growth conditions. BMC Microbiol. 2008, 8. [CrossRef]

10. Anderson, R.D.; Roddam, L.F.; Bettiol, S.; Sanderson, K.; Reid, D.W. Biosignificance of bacterial cyanogenesis in the CF lung. J. Cyst. Fibros. 2010, 9, 158-164. [CrossRef]

11. Gilchrist, F.J.; Alcock, A.; Belcher, J.; Brady, M.; Jones, A.; Smith, D.; Španĕl, P.; Webb, K.; Lenney, W. Variation in hydrogen cyanide production between different strains of Pseudomonas aeruginosa. Eur. Respir. J. 2011, 38, 409-414. [CrossRef]

12. Neerincx, A.H.; Linders, Y.A.M.; Vermeulen, L.; Belderbos, R.A.; Mandon, J.; van Mastrigt, E.; Pijnenburg, M.W.; van Ingen, J.; Mouton, J.W.; Kluijtmans, L.A.J.; et al. Hydrogen cyanide emission in the lung by Staphylococcus aureus. Eur. Respir. J. 2016, 48, 577-579. [CrossRef] [PubMed]

13. Xu, Z.; Chen, X.; Kim, H.N.; Yoon, J. Sensors for the optical detection of cyanide ion. Chem. Soc. Rev. 2010, 39, 127-137. [CrossRef] [PubMed]

14. Ashton, T.D.; Jolliffe, K.A.; Pfeffer, F.M. Luminescent probes for the bioimaging of small anionic species in vitro and in vivo. Chem. Soc. Rev. 2015, 44, 4547-4595. [CrossRef] [PubMed]

15. Lou, X.D.; Ou, D.X.; Li, Q.Q.; Li, Z. An indirect approach for anion detection: The displacement strategy and its application. Chem. Commun. 2012, 48, 8462-8477. [CrossRef]

16. Wang, F.; Wang, L.; Chen, X.Q.; Yoon, J.Y. Recent progress in the development of fluorometric and colorimetric chemosensors for detection of cyanide ions. Chem. Soc. Rev. 2014, 43, 4312-4324. [CrossRef]

17. Li, Z.; Lou, X.; Yu, H.; Li, Z.; Qin, J. An Imidazole-Functionalized Polyfluorene Derivative as Sensitive Fluorescent Probe for Metal Ions and Cyanide. Macromolecules 2008, 41, 7433-7439. [CrossRef]

18. Zeng, Q.; Cai, P.; Li, Z.; Qin, J.; Tang, B.Z. An imidazole-functionalized polyacetylene: Convenient synthesis and selective chemosensor for metal ions and cyanide. Chem. Commun. 2008, 1094-1096. [CrossRef]

19. Chen, X.Q.; Nam, S.W.; Kim, G.H.; Song, N.; Jeong, Y.; Shin, I.; Kim, S.K.; Kim, J.; Park, S.; Yoon, J. A near-infrared fluorescent sensor for detection of cyanide in aqueous solution and its application for bioimaging. Chem. Commun. 2010, 46, 8953-8955. [CrossRef]

20. Nam, S.W.; Chen, X.; Lim, J.; Kim, S.H.; Kim, S.T.; Cho, Y.H.; Yoon, J.; Park, S. In Vivo Fluorescence Imaging of Bacteriogenic Cyanide in the Lungs of Live Mice Infected with Cystic Fibrosis Pathogens. PLoS ONE 2011, 6, e21387. [CrossRef] 
21. Divya, K.P.; Sreejith, S.; Balakrishna, B.; Jayamurthy, P.; Anees, P.; Ajayaghosh, A. A Zn ${ }^{2+}$-specific fluorescent molecular probe for the selective detection of endogenous cyanide in biorelevant samples. Chem. Commun. 2010, 46, 6069-6071. [CrossRef]

22. Lou, X.D.; Zhang, L.Y.; Qin, J.G.; Li, Z. An alternative approach to develop a highly sensitive and selective chemosensor for the colorimetric sensing of cyanide in water. Chem. Commun. 2008, 5848-5850. [CrossRef] [PubMed]

23. Lee, J.H.; Jeong, A.R.; Shin, I.S.; Kim, H.J.; Hong, J.I. Fluorescence Turn-On Sensor for Cyanide Based on a Cobalt(II)-Coumarinylsalen Complex. Org. Lett. 2010, 12, 764-767. [CrossRef] [PubMed]

24. Liu, Y.L.; Lv, X.; Zhao, Y.; Liu, J.; Sun, Y.Q.; Wang, P.; Guo, W. A Cu(II)-based chemosensing ensemble bearing rhodamine B fluorophore for fluorescence turn-on detection of cyanide. J. Mater. Chem. 2012, 22, 1747-1750. [CrossRef]

25. Wu, J.; Kwon, B.; Liu, W.; Anslyn, E.V.; Wang, P.; Kim, J.S. Chromogenic/Fluorogenic Ensemble Chemosensing Systems. Chem. Rev. 2015, 115, 7893-7943. [CrossRef] [PubMed]

26. Baud, F.J.; Barriot, P.; Toffis, V.; Riou, B.; Vicaut, E.; Lecarpentier, Y.; Bourdon, R.; Astier, A.; Bismuth, C. Elevated Blood Cyanide Concentrations in Victims of Smoke Inhalation. N. Engl. J. Med. 1991, 325, 1761-1766. [CrossRef] [PubMed]

27. 2018 Drinking Water Standards and Advisory Tables: United States Environmental Protection Agency. Available online: https://www.epa.gov/sites/production/files/2018-03/documents/dwtable2018.pdf (accessed on 1 July 2019).

28. McAnalley, B.H.; Lowry, W.T.; Oliver, R.D.; Garriott, J.C. Determination of Inorganic Sulfide and Cyanide in Blood Using Specific Ion Electrodes: Application to the Investigation of Hydrogen Sulfide and Cyanide Poisoning. J. Anal. Toxicol. 1979, 3, 111-114. [CrossRef]

29. Blackledge, W.C.; Blackledge, C.W.; Griesel, A.; Mahon, S.B.; Brenner, M.; Pilz, R.B.; Boss, G.R. New Facile Method to Measure Cyanide in Blood. Anal. Chem. 2010, 82, 4216-4221. [CrossRef]

30. Fernandes, G.E.; Ugwu, C. $\mathrm{Cu}^{2+}$ sensing via noncovalent complexes of fluorescent whitening agents and imidazole-based polymeric dye transfer inhibitors. J. Appl. Polym. Sci. 2020, 137, 48915. [CrossRef]

31. Wicholas, M.; Wolford, T. Stable cyanide complexes of copper(II). Inorg. Chem. 1974, 13, 316-318. [CrossRef]

32. Kavallieratos, K.; Rosenberg, J.M.; Chen, W.-Z.; Ren, T. Fluorescent Sensing and Selective Pb(II) Extraction by a Dansylamide Ion-Exchanger. J. Am. Chem. Soc. 2005, 127, 6514-6515. [CrossRef]

33. Zheng, Y.; Orbulescu, J.; Ji, X.; Andreopoulos, F.M.; Pham, S.M.; Leblanc, R.M. Development of Fluorescent Film Sensors for the Detection of Divalent Copper. J. Am. Chem. Soc. 2003, 125, 2680-2686. [CrossRef] [PubMed]

34. Lippert, J.L.; Robertson, J.A.; Havens, J.R.; Tan, J.S. Structural studies of poly(N-vinylimidazole) complexes by infrared and Raman spectroscopy. Macromolecules 1985, 18, 63-67. [CrossRef]

35. Trojer, M.A.; Mårtensson, A.; Nydén, M. Replacement of H-bonded bridged water by transition metal ions in poly(1-vinylimidazole-co-methylmethacrylate) copolymers: A vibrational spectroscopy study using mid-FTIR, far-FTIR and ab initio calculations. Vib. Spectrosc. 2012, 61, 38-42. [CrossRef]

36. Andersson, M.; Hansson, Ö.; Öhrström, L.; Idström, A.; Nydén, M. Vinylimidazole copolymers: Coordination chemistry, solubility, and cross-linking as function of $\mathrm{Cu}^{2+}$ and $\mathrm{Zn}^{2+}$ complexation. Colloid Polym. Sci. 2011, 289, 1361-1372. [CrossRef]

37. Crerar, D.A.; Barnes, H.L. Ore solution chemistry; V, Solubilities of chalcopyrite and chalcocite assemblages in hydrothermal solution at 200 degrees to 350 degrees C. Econ. Geol. 1976, 71, 772-794. [CrossRef]

38. Young, C.A.; Dahlgren, E.J.; Robins, R.G. The solubility of copper sulfides under reducing conditions. Hydrometallurgy 2003, 68, 23-31. [CrossRef]

39. Jha, S.; Calvert, J.W.; Duranski, M.R.; Ramachandran, A.; Lefer, D.J. Hydrogen sulfide attenuates hepatic ischemia-reperfusion injury: Role of antioxidant and antiapoptotic signaling. Am. J. Physiol. Heart Circ. Physiol. 2008, 295, H801-H806. [CrossRef]

40. Jones, D.P. Radical-free biology of oxidative stress. Am. J. Physiol. Cell Physiol. 2008, 295, C849-C868. [CrossRef]

41. Kimura, H. Hydrogen sulfide: From brain to gut. Antioxid Redox Signal 2010, 12, 1111-1123. [CrossRef]

42. Cutting, K. Wound Exudate: Composition and Functions. Br. J. community Nurs. 2003, 8. [CrossRef]

43. Neilands, J.B. Siderophores: Structure and Function of Microbial Iron Transport Compounds. J. Biol. Chem. 1995, 270, 26723-26726. [CrossRef] [PubMed]

44. Vinnakota, C.V.; Peetha, N.S.; Perrizo, M.G.; Ferris, D.G.; Oda, R.P.; Rockwood, G.A.; Logue, B.A. Comparison of cyanide exposure markers in the biofluids of smokers and non-smokers. Biomarkers 2012, 17, 625-633. [CrossRef] [PubMed] 
45. Tsuge, K.; Kataoka, M.; Seto, Y. Cyanide and Thiocyanate Levels in Blood and Saliva of Healthy Adult Volunteers. J. Health Sci. 2000, 46, 343-350. [CrossRef]

46. Jackson, R.; Oda, R.P.; Bhandari, R.K.; Mahon, S.B.; Brenner, M.; Rockwood, G.A.; Logue, B.A. Development of a Fluorescence-Based Sensor for Rapid Diagnosis of Cyanide Exposure. Anal. Chem. 2014, 86, 1845-1852. [CrossRef]

47. David, S.; Patrik, Š.; Francis, J.G.; Warren, L. Hydrogen cyanide, a volatile biomarker of Pseudomonas aeruginosa infection. J. Breath Res. 2013, 7, 044001.

48. Mohammed, A.; Matt, B.; Mohamed, B.; Teresa, A.R.; Riina, R.R.; Ardeshir, B. Volatile organic compound detection as a potential means of diagnosing cutaneous wound infections. Wound Repair Regen. 2017, 25, 574-590. [CrossRef]

49. Yin, K.; Wu, Y.; Wang, S.; Chen, L. A sensitive fluorescent biosensor for the detection of copper ion inspired by biological recognition element pyoverdine. Sens. Actuators B Chem. 2016, 232, 257-263. [CrossRef]

50. Cao, W.; Zheng, X.J.; Fang, D.C.; Jin, L.P. A highly selective and sensitive Zn(II) complex-based chemosensor for sequential recognition of $\mathrm{Cu}(\mathrm{II})$ and cyanide dagger. Dalton Trans. 2014, 43, 7298-7303. [CrossRef]

51. Guo, Y.Y.; Tang, X.L.; Hou, F.P.; Wu, J.; Dou, W.; Qin, W.W.; Ru, J.X.; Zhang, G.L.; Liu, W.S.; Yao, X.J. A reversible fluorescent chemosensor for cyanide in $100 \%$ aqueous solution. Sens. Actuators B Chem. 2013, 181, 202-208. [CrossRef]

52. ASTM D2036-09. Standard Test Methods for Cyanides in Water; ASTM International: West Conshohocken, PA, USA, 2015.

53. Pourmand, N.; Sanagi, M.M.; Naim, A.A.; Wan Ibrahim, W.A.; Baig, U. Dispersive micro-solid phase extraction method using newly prepared poly(methyl methacrylate) grafted agarose combined with ICP-MS for the simultaneous determination of $\mathrm{Cd}, \mathrm{Ni}, \mathrm{Cu}$ and $\mathrm{Zn}$ in vegetable and natural water samples. Anal. Methods 2015, 7, 3215-3223. [CrossRef]

54. Aksu, Z.; Eğretli, G.; Kutsal, T. A comparative study of copper(II) biosorption on Ca-alginate, agarose and immobilized C. vulgaris in a packed-bed column. Process Biochem. 1998, 33, 393-400. [CrossRef]

55. Cerchiaro, G.; Sant'Ana, A.C.; Temperini, M.L.; da Costa Ferreira, A.M. Investigations of different carbohydrate anomers in copper(II) complexes with D-glucose, D-fructose, and D-galactose by Raman and EPR spectroscopy. Carbohydr. Res. 2005, 340, 2352-2359. [CrossRef] [PubMed]

56. Rendleman, J.A. Metal-polysaccharide complexes-Part I. Food Chem. 1978, 3, 47-79. [CrossRef]

57. Rendleman, J.A. Metal-polysaccharide complexes-Part II. Food Chem. 1978, 3, 127-162. [CrossRef]

58. Pereira, L.; Sousa, A.; Coelho, H.; Amado, A.M.; Ribeiro-Claro, P.J. Use of FTIR, FT-Raman and 13C-NMR spectroscopy for identification of some seaweed phycocolloids. Biomol. Eng. 2003, 20, 223-228. [CrossRef]

59. Samiey, B.; Ashoori, F. Adsorptive removal of methylene blue by agar: Effects of $\mathrm{NaCl}$ and ethanol. Chem. Cent. J. 2012, 6, 14. [CrossRef]

60. Seow, W.Y.; Hauser, C.A.E. Freeze-dried agarose gels: A cheap, simple and recyclable adsorbent for the purification of methylene blue from industrial wastewater. J. Environ. Chem. Eng. 2016, 4, 1714-1721. [CrossRef]

61. Kshitij, T.; Gaurav, S.; Kumar, A.R. Adsorption removal of malachite green dye from aqueous solution. Rev. Chem. Eng. 2018, 34, 427-453. [CrossRef]

62. Van Tran, V.; Park, D.; Lee, Y.-C. Hydrogel applications for adsorption of contaminants in water and wastewater treatment. Environ. Sci. Pollut. Res. 2018, 25, 24569-24599. [CrossRef]

63. Gold, D.H.; Gregor, H.P. Metal-Polyelectrolyte Complexes. VIII. The Poly-N-Vinylimidazole-Copper(II) Complex. J. Phys. Chem. 1960, 64, 1464-1467. [CrossRef]

64. Bauman, J.E.; Wang, J.C. Imidazole Complexes of Nickel(II), Copper(II), Zinc(II), and Silver(I). Inorg. Chem. 1964, 3, 368-373. [CrossRef]

65. Trojer, M.A.; Movahedi, A.; Blanck, H.; Nydén, M. Imidazole and Triazole Coordination Chemistry for Antifouling Coatings. J. Chem. 2013, 2013, 946739. [CrossRef]

(C) 2020 by the authors. Licensee MDPI, Basel, Switzerland. This article is an open access article distributed under the terms and conditions of the Creative Commons Attribution (CC BY) license (http://creativecommons.org/licenses/by/4.0/). 